\title{
JORGE AMADO E SEUS CAMARADAS NO CÍRCULO COMUNISTA INTERNACIONAL ${ }^{1}$
}

\section{OS LATINO-AMERICANOS NAS REVISTAS CULTURAIS COMUNISTAS FRANCESAS}

É conhecida a influência intelectual francesa sobre o Brasil, em particular - e a América Latina, em geral - pelo menos até os anos 1960. Isso vale também para o pensamento e a ação de artistas e intelectuais de esquerda. Este artigo busca elucidar alguns aspectos da relação de artistas brasileiros e latino-americanos com a imprensa cultural comunista francesa do fim da década de 1940 a meados dos anos 1950, bem como sua inserção no movimento comunista internacional.

Vivia-se o começo da Guerra Fria, quando o aumento da repressão aos comunistas na América Latina levou alguns artistas da região a buscar abrigo em Paris, onde eram acolhidos por seus correligionários do Partido Comunista Francês (PCF). Eles tinham em comum o alinhamento com a União Soviética e a identificação com seu líder, Stálin. Eram anos de predominância do realismo socialista de Zdanov, responsável pelas formulações culturais no período stalinista. Tratava-se de uma arte pedagógica, comprometida com a propaganda do comunismo, a exaltação de seus feitos e do papel dirigente do partido de vanguarda, além da criação de "heróis positivos", em contraste com a cultura burguesa, tida como decadente e pessimista, expressa no "formalismo". Jorge Amado escrevia, na época, que era preciso "colocar o conteúdo numa forma simples e pura, mais próxima e acessível à grande massa, ávida de cultura" (Amado et al., 1946: 28).

O PCF ganhara popularidade no pós-guerra, fortalecido pela atuação na resistência à ocupação nazista, tendo chegado a obter quase um terço dos votos nas eleições legislativas. Seu prestígio evidenciava-se também nas inúmeras publicações vinculadas ao Partido, inclusive nos meios intelectuais. ${ }^{2}$

Independente de qualquer atribuição valorativa sobre os limites do stalinismo e do realismo socialista então vigentes, não seria possível negar o esforço dos comunistas em geral, e dos franceses em particular, para criar vias alternativas de expressão popular, organizando veículos de imprensa, biblio- 
tecas, comitês culturais, competições esportivas e iniciativas de educação que buscavam dar vez e voz às classes trabalhadoras. O acesso ao mundo das artes e da cultura foi alcançado, por intermédio dos comunistas, por muitos jovens franceses despossuídos.

O PCF comandou, direta ou indiretamente, na época, um amplo conjunto de periódicos, capitaneados pelo seu diário L’Humanité e outros de grande difusão, como o vespertino Ce Soir. Havia também uma gama de publicações com maior espaço para temas de cultura, como La Pensée, La Nouvelle Critique, Les Lettres Françaises, Europe, Action e Arts de France.

Os assuntos que predominavam no debate intelectual dos meios comunistas e simpatizantes, de fins dos anos 1940 ao começo dos 1950, eram as questões atômica e da paz; a Guerra; o macartismo, patente em episódios destacados na imprensa comunista, como a execução do casal Rosenberg, por espionagem nos EUA, em 1953; o caso Lysenko, "cientista" que os soviéticos acreditavam que revolucionaria a genética; o zdanovismo e o stalinismo nas artes e na vida intelectual.

Assim, questões da América Latina ficavam relegadas a segundo plano, exceto quando algum abalo político na região ligava-se aos temas centrais, como, por exemplo, expressava o texto de capa de Les Lettres Françaises "os ocultos [dessous] da revolta colombiana", em que se comentava a situação política nesse país, em 1948, com influência imperialista norte-americana (Les Lettres Françaises, 1948d: 1 e 3 - daqui em diante LLF). Em sentido parecido, a revista La Nouvelle Critique - que quase nunca se voltava para a América Latina - publicou artigo de Pierre Hervé, "Do Irã à Guatemala, o rosto do imperialismo”, em que a referência se dava no contexto de golpes de Estado apoiados pelos Estados Unidos (La Nouvelle Critique, 1954: 23-29).

Além desse foco mais imediatamente político, as publicações culturais comunistas que tematizaram com mais assiduidade o Brasil e a América Latina foram Europe e Les Lettres Françaises. Ademais, abriram suas páginas para escritores da região refugiados na França, que recebiam pela contribuição e eram assim ajudados a manter-se no exílio.

Europe, revista mensal em formato de livro, tratava de temas de arte e cultura, especialmente de literatura. Ela havia sido fundada em 1923 por um grupo de escritores humanistas em torno de Roman Rolland, e desapareceu em 1939, no contexto da Segunda Guerra. Voltou a circular em nova fase, tendo como redator-chefe Jean Cassou - um companheiro de viagem dos comunistas, como se dizia na época - e Jean Fouquet como secretário. Europe é das raras revistas do período que existem até hoje, tornou-se independente financeira e editorialmente do PCF pelo menos desde 1993.

Vários intelectuais comunistas integravam a revista, que, entretanto, era plural, sobretudo no pós-guerra, vindo a cair inteiramente na órbita do PCF em meados de 1949, quando a maré montante da Guerra Fria afetou todas as 
publicações comunistas. A revista sofreu certo abalo quando Jean Cassou deixou a direção, substituído por Pierre Abraham, tendo como secretário de redação Pierre Gamarra. Estes dois últimos eram militantes comunistas, inteiramente afinados com a linha do realismo socialista que passava a ser imposta.

Uma das publicações mais importantes no âmbito cultural foi Les Lettres Françaises, autointitulada "grande hebdomadário literário, artístico e político". Tratava-se de um semanário em formato de jornal, que inicialmente fora o periódico clandestino do Comitê Nacional dos Escritores (CNE). Surgido em 1941, publicou 20 números durante a ocupação nazista. Foi lançado legalmente em setembro de 1944, logo após a liberação de Paris. No pós-guerra, passou a ser mantido pelo PCF e dirigido por Claude Morgan até 1953, e depois por Louis Aragon. Existiu até 1972, com circulação mensal. Sua posição contrária à invasão da Tchecoslováquia em 1968 levou à perda de assinaturas oficiais no Leste Europeu e na URSS, e a desentendimentos no seio do PCF, o que acabou tornando a publicação inviável economicamente. Nos anos 1940 e 1950 ela seguia as posições comunistas oficiais, embora abrigasse artistas que mantinham considerável autonomia criativa, apesar de serem ligados ao PCF, como Pablo Picasso.

Tanto Les Lettres Françaises como Europe deram espaço, em suas páginas, para artistas comunistas latino-americanos exilados em Paris no fim dos anos 1940 e início da década de 1950, como Pablo Neruda, Jorge Amado e Nicolás Guillén, que integraram o círculo comandado por Aragon, o famoso escritor comunista que era o principal expoente e organizador partidário no meio intelectual.

$\mathrm{O}$ autor latino-americano mais mencionado e louvado pelas publicações comunistas francesas foi o poeta Pablo Neruda, militante do PC chileno. Por exemplo, no número 25 de Europe, aparecia seu artigo "Crise democrática no Chile”, apresentado por Louis Aragon (Europe, 1948a: 28-49). Neruda denunciava o presidente chileno Gabriel Gonzales Videla pela política reacionária que o levou a romper relações com países comunistas, num contexto em que o poeta e senador comunista se viu forçado a deixar o Chile, estabelecendo-se em Paris no começo da Guerra Fria.

Europe abriu sua edição de maio de 1948 com o poema de Neruda, "Crônica de 1948 (América)", em que ele dedicava versos a vários países da América Latina, como o Brasil, contemplado na parte IV do texto, que teve fragmentos publicados também em Les Lettres Françaises, em que frequentemente apareciam poemas do autor e matérias sobre ele (Europe, 1948b: 1-9). Neruda manteve-se na onda ao longo dos anos 1950; por exemplo, publicaram-se o poema Canto geral (LLF, 1950b: 2), e uma entrevista com ele realizada por Jean Marcenac, destacada na capa de Les Lettres Françaises, em que se enfatizava o tema da paz, no contexto dos esforços comunistas de então na "luta internacional pela paz" (LLF, 1951a: 1 e 8). O poema de Neruda France fleurie, reviens [França florida, regresse], com chamada de capa, ocupava meia página em fevereiro de 1954 (LLF, 1954b: 10). Em agosto daquele ano, três livros de Neruda seriam resenhados por André Wurmser (LLF, 1954d: 3). 
Jorge Amado foi o artista brasileiro preferido e mais destacado pelas publicações comunistas, especialmente em 1948 e 1949, anos em que esteve exilado em Paris e integrou-se ao meio comunista francês e também internacional, que tinha nessa cidade um dos principais pontos de confluência de suas redes intelectuais. Com apresentação de Georges Soria, Europe publicou trecho de $\mathrm{O}$ cavaleiro da esperança, o famoso livro de Amado sobre Luiz Carlos Prestes (Europe, 1949b: 151-166). Na mesma revista, Pierre Gamarra fez um breve comentário elogioso à tradução francesa de Mar morto. Segundo ele, o romance seria "repleto de lirismo e de canções, e, entretanto, realista, o que prova uma vez mais que a dignidade está do lado da 'gente simples'." A nota terminava lamentando o fato de Amado ter sido obrigado a sair da França, com o visto de permanência suspenso pelo governo (Europe, 1950: 105-106).

Com a cassação de seu mandato de deputado federal constituinte por São Paulo, em consequência da proibição das atividades do Partido Comunista do Brasil (PCB), Jorge Amado passara a ser perseguido e - em comum acordo com a direção partidária - sairia do país em janeiro de 1948. O intuito era denunciar no exterior o retrocesso democrático no governo Dutra, aproveitando-se do fato de Amado já ser, na época, um escritor consagrado no Brasil e conhecido em âmbito internacional, com obras traduzidas que lhe davam visibilidade e credibilidade. Amado ajudou a organizar eventos com esse objetivo, na França e em outros países, e acabou ocupando um lugar central na articulação internacional dos artistas e intelectuais pró-soviéticos.

Inicialmente, Amado planejava morar na Itália com a esposa Zélia e o filho recém-nascido, mas a derrota eleitoral do Partido Comunista Italiano (PCI) levou a que se estabelecessem em Paris, onde viveram até serem forçados a deixar o país no final de 1949. Durante sua temporada na França, Amado tornou-se um dos principais líderes do movimento mundial pela paz, que mobilizava os comunistas de todo o Globo, tendo realizado inúmeras viagens, sobretudo aos países do Leste Europeu, num contexto em que a União Soviética se via ameaçada pela escalada atômica da Guerra Fria, num tempo em que apenas os Estados Unidos tinham a bomba atômica (o primeiro artefato soviético viria em 1949). ${ }^{3}$ Também tiveram de retirar-se da França alguns brasileiros do grupo de artistas e intelectuais comunistas próximos de Amado, bem como Neruda e outros latino-americanos. Amado ficaria 16 anos sem poder retornar ao país. Quando ele já deixara Paris havia mais de ano, Europe abriu a edição com Le mur de pierre, um trecho de seu romance Os subterrâneos da liberdade, ainda em elaboração (Europe, 1951a: 1-8).

No exílio, Jorge Amado e sua mulher, Zélia Gattai, foram amparados por extensa rede de solidariedade comunista, de comitês de bairro em países como Itália e França, até a alta cúpula cultural no Leste Europeu, travando contato com artistas renomados e com dirigentes do movimento comunista internacional. Visitaram fábricas, creches, clubes operários, além das altas rodas artísticas. 
Recebiam, e sempre que podiam aceitavam, convites frequentes para visitar os países comunistas, em geral gratuitamente. Estiveram de férias ou a trabalho na União Soviética, Tchecoslováquia, Polônia, Hungria, Romênia, Alemanha Oriental, Bulgária, sempre hospedados nos locais mais finos, com intérpretes e guias à disposição, recebidos por autoridades do mundo artístico e cultural, e mesmo político, em sentido estrito, dado o papel de Amado no movimento internacional pela paz. Todos os países comunistas tinham sua União dos Escritores, os artistas gozavam de uma série de regalias relativas se estivessem afinados com o regime, como viagens internacionais, hospedagem em bons hotéis, publicações em largas tiragens, participações em encontros e festivas (de cinema, música, teatro, literatura etc.), casas de férias e retiro para escrever em locais privilegiados, como o castelo dos escritores de Dobris, a 40 quilômetros de Praga, onde o casal Amado viria a morar depois de expulso da França, atestando a solidariedade internacionalista nos meios artísticos e intelectuais afinados com os regimes comunistas.

Les Lettres Françaises publicou em matéria de capa o texto de Jorge Amado intitulado "Mensagem de esperança", escrito logo ao chegar ao exílio francês, com direito a enorme foto, em que o líder comunista brasileiro Luiz Carlos Prestes aparecia entre Amado e Neruda (LLF, 1948a: 1 e 3). Tratava-se de homenagem expressa ao secretário geral do PCB, que fora posto na ilegalidade, em matéria afinada com similares que se faziam na França para saudar o secretário Maurice Thorez e, em escala internacional, para louvar Stálin. No mesmo número, também com chamada de capa, publicou-se uma entrevista de Pierre Daix com “o grande romancista brasileiro Jorge Amado" (LLF, 1948a: 4).

Talvez o ápice da presença de Jorge Amado em Les Lettres Françaises tenha sido a publicação de seu romance Seara vermelha (Les chemins de la faim), com xilogravuras de Carlos Scliar, pintor comunista gaúcho, que também vivia em Paris na época. Foi publicado como uma espécie de folhetim entre os números 246 e 273, em 1949 e 1950. O autor seria saudado em "Jorge Amado e a Ilíada", resenha laudatória típica do período stalinista, quando da publicação francesa de seus livros Mar morto e $O$ cavaleiro da esperança. A matéria foi escrita por um dos campeões da estética do realismo socialista na França, André Wurmser, que dizia "Aragon, Ehrenburg, Cholokov, Amado: nós vivemos os tempos de grandeza, o tempo dos heróis, dos mártires, das legendas, das epopeias" (LLF, 1950a: 3).

A conhecida historiadora Annie Kriegel, que viria a romper com o PCF, escreveu em suas memórias que os livros de Amado e de Neruda - juntamente com os de outros autores considerados clássicos pelos comunistas, como Gorki, Dickens, Tolstoi e Dostoievski - eram vendidos por toda a França em campanhas de divulgação promovidas por estudantes do PCF em 1952 e 1953, que envolviam a publicação de "clássicos do povo", de autores franceses, e de "clássicos estrangeiros". Em várias células comunistas, essas obras integravam as "bibliotecas das batalhas do livro" (Kriegel, 1991). Além de divulgar ideias 
e ideais comunistas, difundiam-se autores da rede de escritores comunistas, na qual Amado ocupava posto de destaque. Esse tipo de atividade inspiraria iniciativas também no Brasil, como a coleção "Romances do povo", dirigida por Jorge Amado para o editorial Vitória, do PCB. Ele escolhia os livros e tradutores da coleção, com lugar de destaque para seus amigos estrangeiros e brasileiros (Amado, 1994: 321).

\section{COMUNISTAS E COMPANHEIROS DE VIAGEM DA AMÉRICA LATINA}

Em novembro de 1948 saiu a matéria "Vozes da América Latina" em Les Lettres Françaises, com relato sobre evento em que poetas da região leram poemas na Maison de la Pensée Française, destacando-se, em meia página, "Um soneto de Nicolás Guillén", cubano, negro e comunista, apresentado por Aragon (LLF, 1948e: 5). Uma entrevista com Guillén apareceria na mesma edição, na qual se denunciava que o poeta comunista haitiano René Depestre foi preso na ilha, com declaração de Guillén e abaixo-assinado de intelectuais franceses (LLF, 1952: 4). ${ }^{4}$ Com o poema Le nom, Guillén voltaria a ter destaque na metade esquerda da capa da edição de março de 1954 (LLF, 1954c: 1). Ele era apresentado por Daniel Anselm como sendo, ao lado de Neruda, um dos dois maiores poetas vivos da América Latina. Seria novamente entrevistado por Charles Dobzynski ao voltar de Moscou, onde estivera no II Congresso dos Escritores Soviéticos, em matéria de capa (LLF, 1955: 1 e 2). O poeta morava então em Paris, de onde seria expulso no fim dos anos 1950 (Guillén, 1985: 131). Encontraria abrigo e emprego na Argentina do presidente Frondizi, graças às gestões de um amigo, o poeta comunista espanhol Rafael Alberti, exilado em Buenos Aires na época, que viria a receber o Prêmio Lênin da Paz em 1964. Com a vitória da revolução cubana, Guillén retornaria à ilha, onde presidiria a União de Escritores e Artistas de Cuba (UNEAC), de 1961 até morrer, em 1989.

O escritor guatelmateco Miguel Ángel Asturias também era assíduo em Les Lettres Françaises. Deu uma entrevista a G. D. Nibaut, publicada no mesmo número que homenageava Stálin, recém-falecido, que tinha na capa um desenho singelo de Picasso retratando "o guia genial", mas, não obstante, causou muita polêmica, pois foi considerado irreverente (LLF, 1953a: 1). ${ }^{5}$ Lendas da Guatemala - tradução francesa do primeiro livro de Asturias, autor à época já consagrado - foi resenhado por F. J. Roy, que louvava "a ligação profunda, íntima, quase carnal com seu povo e seu país” (LLF, 1954a: 2). Em suas memórias, Pablo Neruda escreveu que Asturias "foi sempre um liberal, bastante afastado da política militante" (1974: 188). Mas era amigo de comunistas, em 1965 viria a ganhar o Prêmio Lênin da Paz, e sua Guatemala entrara na onda de esquerda com o governo de Arbenz, que assumiu em 1951 e foi derrubado em 1954.

Em razão do golpe militar na Guatemala, apoiado pelos Estados Unidos, o país mereceu a capa de Les Lettres Françaises, com o artigo de Alice Ahrweiler, "A 
Guatemala no coração". Na mesma edição encontrava-se o poema de Aragon a respeito, intitulado "O 19 de junho de 1954" (LLF, 1954e: 1 e 5). A caminho do exílio, destituído do cargo de embaixador em El Salvador pelo caudilho Castillo Armas, Asturias foi entrevistado por Armand Gatti em matéria na capa do periódico.

Não eram apenas artistas comunistas que tinham sua obra destacada por Les Lettres Françaises, que via também em autores não-comunistas aspectos que os aproximariam da estética difundida pela revista, bem como de sua linha política anti-imperialista. Seria exemplo a matéria da coluna "A música", em que Des Ursins escreveu sobre "O caso Villa-Lobos". O compositor foi elogiado por retomar o folclore, percorrer o Brasil, frequentar músicos do povo, valorizando as fontes populares nacionais, em contraste com o formalismo e o cosmopolismo em voga. Ao mesmo tempo, era criticado por se deixar levar pela "abstração", que não seduziria ninguém, como em sua $6^{\text {a }}$ Sinfonia, de 1944. A verdadeira face de Villa-Lobos estaria em composições como Caixinha de Boas Festas, de 1932, que revelaria o "homem de coração simples e bom, ligado a seu chão é à música de seu país". Assim, a matéria rejeitaria "aspectos negativos de certas obras de Villa-Lobos", tidas como abstratas, mas ressaltava que prevaleceria no conjunto o autor de "inspiração popular", realista (LLF, 1951b: 6).

Les Lettres Françaises dava espaço para artistas que eram considerados companheiros de viagem dos comunistas, como Charles Chaplin e Federico Fellini nos anos 1950. Para dar um exemplo brasileiro, Alberto Cavalcanti foi entrevistado por Marine Monod, com chamada de capa, tendo por mote sua adaptação cinematográfica da peça Senhor Puntila e seu criado Matti, de Bertold Brecht (LLF, 1956b: 1 e 7). ${ }^{6}$ Alberto Cavalcanti daria nova entrevista em uma enquete sobre o que seria a vanguarda em 1958, já num contexto de desestalinização (LLF, 1958: 1 e 6).

O filme $O$ cangaceiro, de Lima Barreto, foi outra obra de artista brasileiro não-comunista que conseguiu destaque em Les Lettres Françaises. Foi resenhado por Josette Daix, que o considerou um "bom filme de aventura", porém de interesse restrito $(L L F, 1953 b) .^{7}$ Isso atestava que a imprensa comunista estava atenta ao que se passava na cena cultural francesa, onde o filme brasileiro obtinha sucesso em 1953.

Os artistas não-comunistas em geral eram tratados com menos benevolência que os comunistas e simpatizantes, como, por exemplo, numa resenha de Anne Villelaur dos livros O desconhecido, de Érico Veríssimo, A divisão das águas, de Alejo Carpentier, Cacau, de Jorge Amado, e O papa verde, de Miguel Ángel Asturias. Veríssimo era o único dentre esses autores traduzidos que estava fora da órbita comunista, talvez por isso só ele era criticado: seu livro não traria qualquer contribuição à literatura brasileira, ao contrário daquele de Amado, mesmo numa obra de juventude que era reeditada na França, a qual já prenunciaria a "maestria do escritor", apesar de ainda não estar maduro, segundo a matéria (LLF, 1956a: 2). 
O Brasil como país tropical, exótico, apareceu em alguns momentos de Les Lettres Françaises. Por exemplo, na cobertura do lançamento em Paris do filme de aventura S.O.S. Noronha, passado na ilha brasileira, mas filmado na Córsega, estrelado por Jean Marais e dirigido por Georges Rouquier (LLF, 1957b: 6). Ou na resenha elogiosa de René Bourdier para o livro de Pierre Joffroy sobre o Brasil, que integrava a coleção "Pequeno planeta", da editora Le Seuil (LLF, 1959a: 5). A atenção ao que se passava no mercado cultural mais abrangente revelava-se, ainda, na cobertura do filme francês vencedor no festival de Cannes, Orfeu negro, de Marcel Camus, rodado no Rio de Janeiro (LLF, 1959b, 1959b).

\section{O IMPACTO DA EXPERIÊNCIA EM PARIS SOBRE JORGE AMADO E SEUS COMPANHEIROS}

Parece que se reproduzia também nos meios de esquerda a relação centro-periferia, nas quais os artistas e intelectuais da América Latina iam aprender com os franceses. Estes não davam mostras de incorporar muito do que se trazia da América Latina. Não há indicadores de ruptura com certo eurocentrismo político e cultural. Por sua vez, em sentido contrário, os contatos na França e no exterior foram fundamentais para a inserção de artistas latino-americanos em redes internacionais, bem como para sua formação intelectual e política.

Foi importante o papel da imprensa comunista francesa para divulgar a obra de artistas latino-americanos que integravam a rede comunista. Alguns deles se tornavam agentes importantes no circuito, incorporando e difundindo práticas internacionais, como fez Jorge Amado ao organizar os "Romances do povo" para o PCB nos anos 1950, após retornar. A experiência no exterior, em particular na França, influenciava também a própria obra dos autores, como o Jorge Amado de Os subterrâneos da liberdade. Seu exílio teria implicações para a introdução no Brasil do realismo socialista nos moldes do que era então compreendido na Europa. ${ }^{8}$

Dentre os brasileiros, Amado foi o principal beneficiário da integração na rede cultural comunista, primeiro no exílio em Paris, depois no castelo dos escritores na Tchecoslováquia. Publicado em diversos idiomas, vencedor do Prêmio Stálin da Paz entre os Povos, em 1951, tornou-se uma espécie de embaixador cultural comunista do Brasil, ajudando escritores, pintores, cineastas e outros artistas a se projetarem e até ganharem prêmios no exterior, dada a sua posição e contatos privilegiados na sociabilidade das redes comunistas. ${ }^{9}$ Voltando ao Brasil em fins de 1952, consolidou sua posição como principal artista comunista. Sem romper formalmente com o PCB, tornou-se apenas um companheiro de viagem após as denúncias dos crimes de Stálin que abalaram os comunistas depois de 1956. Mas continuou por um bom tempo na órbita comunista, como atesta o relato de Zélia Gattai sobre a visita de Giocondo Dias 
a Amado em 1960, a fim de transmitir a diretiva de votar no general Lott nas eleições presidenciais contra Jânio Quadros (Gattai, 2011: 16).

Os livros de memórias de Zélia Gattai, em especial Senhora dona do baile (2009a), relembram vários episódios do tempo em que viveu com Jorge Amado no Grand Hôtel Saint-Michel, na rue Cujas, em Paris, que Amado descreveu como "reduto de comunas latino-americanos e lusos, literatos e artistas de preferência" (1994: 551). Tratava-se de um alojamento simples, onde também viviam outros brasileiros, como o pintor gaúcho Carlos Scliar, que ficara na Europa após o fim da Segunda Guerra, quando fora recrutado pela Força Expedicionária Brasileira.

Zélia nomeou grande número de artistas, cientistas e intelectuais franceses com quem teve contato ao lado de Jorge Amado, em geral no círculo de comunistas e simpatizantes, caso de Irène e Frédéric Joliot-Curie, ganhadores do Nobel de Química em 1935, e escritores como "Paul Éluard, Louis Aragon, Elsa Triolet, Vercors, Roger Vailland, Claude Roy, Pierre Daix, Claude Morgan, Pierre Gamarra, Renaud de Jouvenel, Pierre Seghers, Andrée Viollis, Aimé Césaire" (Gattai, 2009a: 349), além de Pablo Picassso, Laurent Casanova e outros. Jorge Amado cultivou contatos que viriam a se estreitar mais tarde também na esquerda de fora do circuito comunista, como aquele com Jean-Paul Sartre.

A ligação com os franceses, entretanto, era, sobretudo, de trabalho e dava-se principalmente em torno da militância de Jorge Amado e outros companheiros. Relatos de Zélia e Jorge expressaram mais intimidade com número mais restrito de locais, como Françoise Leclercq, católica de origem aristocrática que lutou na Resistência à ocupação alemã, ou, ainda, o casal Georgette e Jean Laffitte, com quem conviveriam posteriormente no castelo dos escritores em Dobris, sem contar algumas empregadas que ajudavam Zélia a cuidar do filho pequeno, além de Madelaine Salvage, proprietária do hotel onde moravam. Jean Laffitte fora eleito secretário geral do Conselho Mundial da Paz, no qual Amado ocuparia lugar de destaque, e viria a tornar-se o principal veículo para a difusão de seu nome, potencializando seus contatos e publicações no exterior.

Ao chegar a Paris, Amado tinha apenas dois livros publicados em francês, ambos pela prestigiosa editora Gallimard, um deles em 1938: Bahia de tous les saints (Jubiabá), que seria reeditado no pós-guerra, quando saiu também Terre violente (Terras do sem-fim), pela mesma editora, em 1946. Sua estada em Paris levou a novas traduções de livros, do fim dos anos 1940 a meados dos 1950, como Mar morto e $O$ cavaleiro da esperança (Le chevalier de l'espérance), que saíram em 1949; Seara vermelha (Les chemins de la faim), e São Jorge dos Ilhéus (La terre aux fruits d'or), em 1951; Capitães de areia (Capitaines sur sable), em 1952; e Cacau (Cacao), em 1955. Foram, em geral, publicados por editoras próximas do PCF, com exceção de Capitães de areia, que saiu pela Gallimard, atestando que Amado não se fechava no universo comunista. Ele participava, ainda, de atividades de divulgação, como a venda anual de livros autografados, patrocinada pelo Comitê Nacional dos Escritores, originário da Resistência. Em suma, a estada em Paris 
potencializou a entrada dos livros de Jorge Amado no mercado francês, como de resto, a seguir, na Europa e no mundo comunista.

A influência de Louis Aragon parece ter sido expressiva sobre Jorge Amado, embora este nunca tenha se integrado ao seu círculo mais próximo. Ela se deu tanto no aspecto político - com a incorporação de Amado ao circuito do movimento internacional pela paz, que tinha em Aragon um dos principais artífices na França - como no aspecto literário. Além de abrir para Amado as portas de editoras e revistas como Les Lettres Françaises e Europe, Aragon fornecia um modelo de escritor engajado. O francês começava a publicar, na época, a obra em seis volumes Os comunistas (Les communistes, 1949-1951), que tratava, sobretudo, da atuação heroica na resistência à ocupação alemã. Trechos do romance de Aragon, ainda no prelo, foram publicados com antecedência por Europe (1949a: 4-26).

Já na Tchecoslováquia, onde se abrigou após ter deixado Paris, Amado escreveria seu romance mais afinado com o realismo socialista, retratando a resistência comunista ao Estado Novo no Brasil, intitulado Os subterrâneos da liberdade. Tanto a temática do livro como a data de sua elaboração, mais o formato em três partes (que, dependendo da edição, corresponderiam a três grossos volumes: 1. Os ásperos tempos, 2. Agonia da noite e 3. A luz no túnel) - algo atípico na obra de Jorge Amado - seriam indicadores da influência de Aragon e do contexto cultural que o baiano viveu no exílio francês.

Na longa biografia de Louis Aragon escrita por Pierre Daix (1994) - que fora o braço direito do biografado nos anos de atuação como jornalista do PCF - quase não há referência a intelectuais ou artistas latino-americanos, mesmo tendo sido Aragon sabidamente um contato fundamental dos escritores da região, como expressam, por exemplo, as memórias de Amado, Neruda, Guilén e Zélia Gattai. Jorge Amado não foi sequer citado por Daix, Neruda foi mencionado de passagem duas vezes (Daix, 1994).

Já Aragon apareceu dez vezes nas anotações memorialísticas de Jorge Amado em Navegação de cabotagem (1994). Este comentava que realizou várias tarefas partidárias com Aragon e atestava que ele fora o responsável pela tradução e publicação de dois de seus livros na França. Mas confessava que não se sentia bem na "corte" que rodeava o principal articulador comunista no meio artístico e intelectual. A aproximação foi mais profissional do que pessoal. Segundo Amado: “Com Aragon não fui além da estima literária e da convivência partidária, por mais de uma vez esbarramos um no outro; Aragon e sua corte, não nasci cortesão, nasci amigo" (1994: 101-102).

O poeta francês era mais próximo de Neruda do que de Amado, que mencionou nas memórias ter encontrado várias vezes "Sua Santidade, o papa Louis" Aragon, por exemplo, na redação do diário comunista Ce Soir, dirigido pelo camarada (Amado, 1994: 207). Mas nunca foi convidado para sua casa, ao contrário de Neruda, que gozava de certa intimidade com Aragon, sua mulher 
russa, Elsa Triolet, e Paul Elouard, como relatou em Confesso que vivi (Neruda, 1974: 246).

A relação parece ter sido assimétrica: Aragon provavelmente foi mais importante para os latino-americanos do que estes para ele, mesmo no caso de Neruda, o mais homenageado. Por exemplo, quatro poemas - escritos por dois dos maiores poetas franceses vivos então, os ex-surrealistas Louis Aragon e Paul Eluard, além de Gilbert Ancian e Claude Sernet - foram dedicados a Neruda nas páginas de Les Lettres Françaises em março de 1948 (LLF, 1948b: 5). A reciprocidade do chileno apareceria no poema Pour Aragon, les fleurs lointaines [Para Aragon, as flores de longe], publicado em parte na capa do mesmo periódico, em comemoração aos 60 anos do francês (LLF, 1957c: 1 e 3).

Retomando as memórias de Jorge Amado, ele relatou episódios com artistas de quem buscou se aproximar na estada em Paris e depois na Tchecoslováquia, até mesmo esquerdistas rivais dos comunistas, como Jean-Paul Sartre. Esta aproximação foi cultivada: primeiro, o pedido bem-sucedido de assinatura do francês num telegrama de intelectuais e artistas ao presidente chileno em protesto contra a perseguição ao poeta Pablo Neruda, em 1948; em seguida, o contato para a publicação de Cacau; depois as viagens em companhia de Sartre e Simone de Beauvoir, quando de sua longa estada no Brasil em 1960, e a subsequente publicação de Quincas Berro d’Água no periódico de Sartre, Les Temps Modernes, em 1961.10

Em Paris, Amado procurou acercar-se ainda de Pablo Picasso, que em 1948 fez um desenho para a capa da edição italiana de Terras do sem fim. As atividades no circuito comunista ajudaram na aproximação, como no episódio de 1949, em que Amado acompanhou o empenho pessoal de Picasso para garantir um visto para a entrada de Neruda na França, a ponto de não estar presente quando nasceu sua filha Paloma, que significa pomba, em espanhol (Amado, 1994: 159). O nome remetia à famosa pomba da paz de Picasso, símbolo do movimento mundial pela paz articulado pelos comunistas.

Tanto as memórias de Jorge Amado (1994: 101), como as de Zélia Gattai (2009a: 151), revelaram que eles foram para a Europa com a expectativa de conhecer de perto alguns de seus escritores preferidos, em geral do circuito comunista ou próximo dele. De fato, conseguiram o intento, sendo que alguns teriam se tornado amigos do casal, como os lusitanos Ferreira de Castro e Alves Redol, o americano Michael Gold, a alemã Anna Seghers e o soviético Ilya Ehrenburg.

O romancista baiano aproveitava cada viagem para fazer novos conhecidos e amigos. Por exemplo, quando foi à Itália, em 1948: "iniciei em Roma minha colheita de amizades, prossegui em Florença", Milão e outros lugares. Conheceu Renato Guttuso, Alberto Moravia, Cesare Zavattini, Carlos Levi, De Santis, Emilio Sereni, Giancarlo Pajetta, Vasco Pratolini, Elio Vittorini e seu tradutor Dario Puccini, entre outros (Amado, 1994: 155). O exílio na França abrira incontáveis portas para a internacionalização. 


\section{JORGE AMADO NO CÍRCULO LATINO-AMERICANO EM PARIS}

Próximos mesmo de Jorge e Zélia eram alguns brasileiros que residiam em Paris, como Carlos Scliar, Jacques Danon, Paulo Rodrigues, Alberto Castiel - além de dezenas de patrícios de passagem pela França. Naquele final da década de 1940, Paris continuava a atrair artistas e intelectuais do Brasil, que se agrupavam em torno de três pontos de referência: o pequeno apartamento onde morava Paulo Emílio Salles Gomes, em Saint-Germain-des-Prés, o escritório de Paulo Duarte, no Museu do Homem, e o Grand Hôtel Saint-Michel, no qual o quarto de Jorge Amado seria a "célula principal do Brasil na Europa Ocidental", segundo depoimento de Fausto Castilho a José Inácio de Melo Souza (2002: 275). Havia contato entre os grupos, que, entretanto, eram diferentes, o de Jorge mais alinhado ao PCB. Seria o "consulado geral da esquerda brasileira", conforme referência da biografia de Nelson Pereira dos Santos, que passou uma temporada em Paris quando era um jovem comunista aprendiz de cinema, tendo chegado à cidade logo depois que Amado a deixara, aproximando-se muito de Carlos Scliar, herdeiro da "célula" (Salem, 1987: 56).

Encontros em Paris contribuíram para estreitar laços entre artistas comunistas da América Latina. As memórias de Jorge Amado e Zélia Gattai são plenas de referências a artistas da região, de quem se aproximaram no exílio francês e na concomitante participação nos movimentos da paz, como o escritor argentino Alfredo Varela, o romancista chileno Volodia Teitelboin, também dirigente comunista, os artistas venezuelanos Adelita e Héctor Poleo, o escritor guatemalteco Miguel Ángel Asturias, o poeta paraguaio Elvio Romero e seu conterrâneo, o compositor popular Assunción Flores (autor da célebre canção Índia), o romancista uruguaio Enrique Amorim, entre outros, como o poeta haitiano René Depestre. Este chegou a ser contratado como secretário de Amado no castelo de Dobris e logo depois morou no Brasil, onde frequentou, em 1953, ao lado de Alina Paim e Jorge Amado, um dos então célebres e clandestinos cursos Stálin promovidos pela direção do PCB (Amado, 1994: 408).

A aproximação mais notória a partir do exílio na França estabeleceu-se entre Jorge Amado, Pablo Neruda e Nicolás Guillén, três escritores comunistas de liderança no meio intelectual de seus respectivos países, que foram amigos e fizeram muitas viagens juntos no circuito comunista, no qual militavam no movimento pela paz mundial.

O poeta cubano Guillén era perseguido naquela passagem dos anos 1940 para os 1950, assim como os outros dois companheiros. Para se ter ideia da importância da estada na França para sua amizade com Amado, basta dizer que ele registrou em suas memórias que conheceu o brasileiro em Paris no ano de 1949 (Guillén, 1985: 121). Esqueceu-se de que o primeiro encontro entre eles fora no Rio de Janeiro, em 1947, num recital de poemas na Associação Brasileira de Imprensa (ABI), como lembrou Jorge Amado. Após o evento que apresentara, 
Jorge teria levado o poeta para o hospital, onde foram conhecer o filho recém-nascido do baiano (Amado, 1994: 21-22).

A imprecisão das memórias revelaria que para Guillén o importante de fato fora conhecer Jorge no contexto do exílio em Paris, quando chegou a morar no mesmo hotel do brasileiro, que lhe apresentou a dona do estabelecimento onde viveria alguns anos (Guillén, 1985: 221; Gattai, 2009a: 335). Já a pretensa precisão de Amado expressaria a importância que dava aos contatos com os intelectuais célebres que recebia, a ponto de estar em atividade com um deles no momento em que nascia seu primeiro filho com Zélia. Ademais, o episódio seria expressivo da rápida aproximação pessoal que procurava estabelecer com artistas que admirava. Geralmente obtinha êxito, como nas amizades travadas com Neruda, Anna Seghers, Ehrenburg e muitos outros. Mas nem sempre era bem-sucedido, como no caso já relatado de Aragon.

Uma terceira versão para o episódio da ABI foi dada por Zélia. Segundo ela, Jorge deixou o recital antes do fim, logo que apresentou Guillén ao público, e ao chegar ao hospital descobriu, incrédulo, que o filho João Jorge já havia nascido. O poeta cubano só a visitaria na manhã seguinte, desculpando-se por ter ocupado Jorge em momento tão especial, e prontificou-se a ser padrinho do menino. Guillén era outro a dar importância às relações pessoais e de compadrio. "Nosso compadre Nicolás! Juntos, com ele e comadre Rosa, sua mulher, corremos mundo em viagens maravilhosas" (Gattai, 2010: 308). Por exemplo, aquela à China, em 1952, três anos após a revolução. Uma segunda viagem à terra de Mao seria realizada na companhia de Pablo Neruda e sua mulher, Matilde, em 1957, por ocasião do Congresso do Conselho Mundial da Paz em Colombo, no Ceilão, atualmente Sri Lanka (Gattai, 2009a: 235; 2011: 109).

Guillén foi personagem assíduo nas memórias de Jorge e Zélia, que apareceram de modo mais comedido na autobiografia do cubano. Ele fez uma referência breve, mas carinhosa e calorosa, ao casal de amigos, não por acaso centrada em sua convivência em Paris (Guillén, 1985: 121-122). Outros artistas brasileiros foram nomeados nas lembranças do poeta sobre suas quatro viagens ao Brasil, realizadas entre 1945 e 1961. Ele se impressionou, sobretudo, com a pessoa, a vida e a obra de Cândido Portinari, a quem dedicou várias páginas (Guillén, 1985: 115-128).

Como era de se esperar, Portinari tinha boa acolhida na imprensa cultural comunista francesa. Por exemplo, o periódico Arts de France deu cobertura extensa sobre sua vida e obra em 1946, por ocasião da primeira exposição do autor em Paris. Ele era apresentado como "o maior pintor da América Latina e um dos maiores pintores contemporâneos", ressaltava-se sua condição de comunista, cuja candidatura ao Congresso Nacional teria levado a ser proibida uma exposição de sua obra em São Paulo. "Portinari, pintor nacional brasileiro" era o título do escrito de Jean Cassou, que comparava a pintura de Portinari à música de Villa-Lobos. No mesmo número, em "Meu amigo Portinari", Emmanuel 
Auriciste destacava sua posição "antitorre de marfim" (Arts de France, 1946: 3-16). Candido Portinari realizaria sua segunda exposição parisiense em 1957, tendo recebido atenção em matéria elogiosa de George Besson, que reproduzia, ainda, fotos de suas obras em Les Lettres Françaises (LLF, 1957a: 12). ${ }^{11}$

Por sua vez, Pablo Neruda dedicou um poema a Jorge Amado na revista Europe. O tema era outro escritor baiano: "Castro Alves do Brasil", em versos traduzidos do espanhol por Alice Ahrweiler (Europe, 1951b: 36-37). Neruda foi lembrado em diversas passagens dos livros de memórias de Zélia Gattai e Jorge Amado, em episódios por todos os cantos do Globo, inclusive nas residências de Neruda, no Chile, e de Amado, no Brasil. A estada na França estreitara as relações entre eles: "Com Pablo Neruda convivêramos em Paris, [...], quando, refugiado político como nós, o poeta chileno lá passara longa temporada”, segundo Zélia Gattai (2010: 309).

As menções ao casal brasileiro foram afetivas, porém mais escassas, no livro memorialístico de Pablo Neruda, por exemplo, quando ele relatou a viagem que fizeram juntos pela Ásia, em 1957 (Neruda, 1974: 233). Não mencionou Amado em suas recordações sobre a concessão dos prêmios Stálin da Paz, em que ambos desempenharam papel relevante, embora o de Neruda tenha sido mais central. Isso talvez se explique pelo fato de Amado ter se afastado da militância comunista, ao contrário de Neruda, ou ainda porque o chileno ocupava o primeiro lugar em prestígio internacional e na relação dos intelectuais latino-americanos com os comunistas no exterior, como se pode comprovar pelas referências prioritárias a ele na imprensa cultural comunista francesa. $\mathrm{Ou}$, simplesmente, porque o compadre chileno tenha sido mais importante para o casal Amado do que vice-versa.

Segundo Neruda, "as revelações sobre a época stalinista haviam quebrantado o ânimo de Jorge Amado". Relatou que eram velhos amigos, compartilharam anos de desterro, identificados "numa convicção e esperança comuns". Mas se julgava menos sectário que o brasileiro, que "tinha sido sempre rígido". Depois do informe de Krushev no XX Congresso do Partido Comunista soviético, o romancista baiano teria se tornado mais tranquilo e sóbrio, pondo-se a "escrever seus melhores livros, a começar por Gabriela, cravo e canela, obra-prima”, em romance já distanciado de um “caráter político direto" (Neruda, 1974: 237).

\section{DE PARIS PARA O MUNDO: JORGE AMADO E O MOVIMENTO INTERNACIONAL PELA PAZ}

A difusão e a repercussão da pessoa e da obra de Jorge Amado foram potencializadas a partir de sua temporada francesa, na qual se integrou ao movimento mundial pela paz. O processo seguiu-se na Tchecoslováquia, nas viagens constantes pela Europa e especialmente pelos países comunistas, até mesmo a China. 
Ele já fora publicado na França, na Itália e no Leste Europeu, mas eram poucas obras, que passaram a ser traduzidas e editadas em maior número nos anos 1950.

Como afirmou Zélia, referindo-se à Romênia - algo que também se podia constatar em outros países -, o prestígio de Amado "provinha também, e sobretudo, de sua atuação na luta pela paz, pelo posto de responsabilidade que ocupava como membro do Bureau do Conselho Mundial da Paz" (Gattai, 2009a: 370). O aumento das traduções de livros de Amado em tcheco, por exemplo, permitiu-lhe viver de direitos autorais no castelo dos escritores em Dobris. Mas tinha de gastar no país tudo que recebia, pois era proibido retirar moeda para o exterior, como relatou Zélia Gattai (2009b: 51). O mesmo acontecia em outros países comunistas que lhe pagavam direito autoral, quando os visitava.

Em 1948, Jorge Amado viajou de Paris a Varsóvia a fim de participar de reunião para preparar o Congresso de Intelectuais pela Paz Mundial, realizado logo em seguida, em agosto. Ficou conhecido como o Congresso de Wroclaw, na Polônia, que atraiu participantes do mundo todo. Amado foi eleito um dos vice-presidentes do Congresso, que abriu com um discurso. A delegação brasileira era composta de artistas e intelectuais que viviam na Cidade Luz e eram próximos do baiano: Carlos Scliar, Claudio Santoro, Vasco Prado, Zora Braga, Ana Stela Schic, Alberto Castiel e outros, como Paulo Emílio Salles Gomes. O físico Mário Schenberg viajou diretamente do Brasil (Amado, 1994: 27-28; Gattai, 2009a: 96).

Não houve pleno consenso no Congresso de Wroclaw, alguns poucos participantes deixaram de assinar o manifesto final por não concordar com seus termos, considerados pró-soviéticos. Entre os brasileiros, o único que se absteve de assinar foi o crítico de cinema Paulo Emílio Salles, que abandonara o PCB anos antes, embora continuasse um homem de esquerda, anti-stalinista. Isso não o teria impedido de continuar mantendo boa relação com Jorge Amado e Carlos Scliar, segundo depoimento deste último (Souza, 2002: 280). Mas Paulo Emílio não foi citado nas memórias de Amado, que muitas vezes preferiu silenciar sobre seus antagonistas; por exemplo, tampouco mencionou Jacob Gorender, Mário Alves, Apolônio de Carvalho e outros líderes importantes do PCB com quem provavelmente se desentendeu. A relação dos comunistas brasileiros de Paris com Paulo Emílio teria se deteriorado no começo dos anos 1950: o cineasta Nelson Pereira dos Santos teria sido aconselhado a não contatar Paulo, tido como trotskista (Souza, 2002: 280).

A falta de consenso não impediria o sucesso do Congresso de Wroclaw, que levou à organização do I Congresso Mundial da Paz, na Salle Pleyel em Paris, em abril de 1949, de cuja organização Jorge Amado participou ativamente, ao lado de franceses como Aragon, Vercors, Laffitte e Frédéric Joliot-Curie, além de muitos estrangeiros, inclusive escritores soviéticos como Ehrenburg e Fadeiev. Afinal, o movimento era importante, sobretudo para a política externa de Stálin, temeroso do avanço nuclear norte-americano. Além de brasileiros que viviam 
na França, embarcaram para o Congresso personalidades como Caio Prado Jr., Paulo Guimarães da Fonseca e Mário Schenberg, juntando-se a artistas e intelectuais de prestígio de muitos países, comunistas ou "companheiros de viagem". Nesse Congresso foi eleito o Conselho Mundial da Paz, que seria sediado em Praga, com personalidades do mundo todo. Jorge Amado foi escolhido para o bureau executivo do Conselho, posição que lhe garantiria contato privilegiado com intelectuais e artistas comunistas em escala planetária (Gattai, 2009a: 314).

O II Congresso Mundial da Paz estava programado para realizar-se em novembro de 1950, em Sheffield, na Inglaterra, mas as dificuldades para conseguir vistos levaram o evento a mudar, em cima da hora, para Varsóvia, na Polônia, onde compareceram delegações numerosas, inclusive do Brasil (Gattai, 2009b: 84 e 113)

Estava aberto o caminho para a projeção em primeiro plano do nome de Jorge Amado nos meios comunistas internacionais, sobretudo na União Soviética e no Leste Europeu, o que levaria o autor a ganhar o Prêmio Internacional Stálin da Paz em dezembro de 1951, que receberia pessoalmente em Moscou, onde foi recepcionado calorosamente em solenidade de janeiro de 1952, na Academia de Ciências da União Soviética. Foi saudado publicamente por seu amigo, o escritor e diplomata Ilya Eherenburg, que fizera parte do júri (Gattai, 2009a: 234; 2009b: 186). O ganho teria sido de cerca de 15 mil dólares, segundo Jorge, ou de 25 mil, na recordação de Zélia, montante doado ao PCB. Os premiados eram "escolhidos por um júri internacional integrado por dirigentes do movimento da paz". Contudo, "os prêmios não eram decididos sem a aprovação dos soviéticos", que os financiavam, como relatou Amado (1994: 105-107; Gattai, 2009b: 181).

Os outros agraciados em 1951 foram a escritora Anna Seghers (muito amiga de Jorge e Zélia, presidente da União dos Escritores da República Democrática Alemã), a britânica Monica Felton e os políticos Oyama Ikuo do Japão e Pietro Nenni da Itália, dirigente do Partido Socialista, então próximo dos comunistas. Nenni devolveria o Prêmio Stálin e doaria o montante recebido à Cruz Vermelha Internacional em 1956, após a invasão da Hungria pelas tropas do Pacto de Varsóvia.

O prêmio - que passaria a levar o nome de Lênin a partir de 1957, após as mudanças políticas na União Soviética - era de muito prestígio na época, pretendia ser uma espécie de contraponto ao Nobel do Ocidente. Tanto que Jorge Amado afirmou, em suas memórias, orgulhar-se dele, mesmo depois de abandonar o stalinismo e o PCB:

Fui stalinista de conduta irreprochável, subchefe da seita, se não bispo ao menos monsenhor, descobri o erro, custou trabalho e sofrimento, deixei a missa em meio, saí de mansinho. Nem por haver-me dado conta e abandonado o redil escondi ou neguei ter recebido, em dia de glória, com honra e emoção inimagináveis, o Prêmio Internacional Stálin [...] momento culminante de minha vida (Amado, 1994: 588-589). 
Essas palavras dão ideia da importância, para Amado, de sua atuação no Conselho Mundial da Paz, bem como para outros artistas comunistas que se sentiam recompensados e consagrados ao receber o prêmio. Ao falar dele no início e no fim de seu livro de memórias, fragmentadas e sem seguir ordem cronológica, Amado reiterava simbolicamente a relevância desse "momento culminante". Recordando-se da época, afirmou que

presidia o júri o presidente da Academia de Ciências da URSS, os vice-presidentes eram o sábio chinês Kuo-Mo-Jo e poeta francês Louis Aragon, dele faziam parte entre outros, Anna Seghers, Ilya Ehrenburg, Pablo Neruda, Alexandre Fadeiev, hoje todos mortos. Membro do comitê Central do PCUS, Fadeiev era o manda-chuva (Amado, 1994: 18).

Todos os nomes citados eram amigos ou bem próximos de Amado, e vários foram agraciados com o mesmo prêmio, atestando a reciprocidade na cúpula do movimento internacional pela paz. Anna Seghers ganhou em 1951, Ilya Ehrenburg em 1952, Pablo Neruda em 1953, Louis Aragon em 1957. Outros contemplados também eram do círculo íntimo de Amado, como Nicolás Guillén, vencedor em 1954. O poeta cubano deu lugar de destaque à láurea na conclusão de sua autobiograria. O Prêmio Stálin teria marcado sua vida, bem como a de todos os agraciados, sempre de "maneira indelével" (1985: 158).

Por sua vez, Pablo Neruda relatou em suas memórias que

Kuo Mo Jo era, além disso, vice-presidente do comitê de prêmios junto com Aragon. A esse mesmo júri pertencíamos Ana Seghers, o cineasta Alexandrov, alguns outros que não recordo, Ehrenburg e eu. Existia uma aliança secreta entre Aragon, Ehrenburg e eu, por meio da qual conseguimos que se desse o prêmio em outros anos a Picasso, a Bertold Brecht e a Rafael Alberti. Não tinha sido fácil, é claro (Neruda, 1974: 207).

A premiação devia ser referendada pela direção do PC soviético, mas havia espaço para os membros do júri eventualmente contemplarem comunistas menos afinados com as diretrizes oficiais, como o teatrólogo alemão Bertold Brecht, ganhador em 1954. Jorge Amado teve pouco contato com ele, mas ajudou a articular o Prêmio Stálin para Brecht, que assim teria ficado fortalecido diante de pressões internas do PC da Alemanha Oriental. Amado foi com Anna Seghers pedir o apoio de "Sacha", como Alexander Fadeiev era conhecido dos íntimos. Seguiam conselho de Aragon, ele sabia que o voto decisivo era o do Secretário Geral da União dos Escritores soviéticos, que, na sua opinião, gostava de Jorge: "Era verdade. Fadeiev me estimava, considerava-me um camarada direito, em quem se podia confiar", nos termos de Amado (1994: 193-194).

De fato, o romancista brasileiro era muito bem situado na rede de poder intelectual comunista, que ajudava a tecer, como "camarada direito", alinhado com as diretrizes do PC soviético. Fadeiev foi personagem constante nas memórias de Zélia Gattai: 
Jorge e eu havíamos almoçado naquele dia com Fadeiev e seu intérprete, e eu me deliciara com as histórias que ele nos contara, entrecortada de gargalhadas estrepitosas. Fadeiev escrevera, nos álbuns dos meninos, palavras de carinho, para nós e para o Brasil (Gattai, 2009a: 145).

O sucessor de Gorki à frente da União dos Escritores soviéticos, colaborador direto de Andrei Zdanov, receberia naquela noite a notícia da morte do chefe e choraria em público durante uma festa de artistas e intelectuais na Polônia, em 1948, na qual Zélia estava com o marido. Fadeiev convidou, logo depois, vários intelectuais a visitar a URSS, como Jorge Amado, de quem se tornara "muito amigo", segundo Zélia Gattai (2009a: 184). O mesmo Fadeiev seria pessoalmente portador do convite para "ir à Geórgia e também à casa onde Stálin nascera, grande privilégio" (Gattai, 2009a: 221).

Jorge Amado desde logo se deu bem com os soviéticos, mas havia exceções: "Apenas conheci Cholokov e de logo o detestei", bêbado, "homem do aparelho do Partido, da intriga e da denúncia", mas "grande, imenso romancista" (Amado, 1994: 102). Em Paris, o baiano aproximou-se daquele que viria a ser seu melhor amigo soviético: Ilya Ehrenburg. Além de escritor reconhecido, ele seria, na época, "uma espécie de porta-voz do governo soviético" sobre política externa, segundo Amado (1994: 128). Mais tarde viria a engajar-se na campanha oficial de desestalinização, publicando obras críticas ao período anterior, como a pioneira O degelo, de 1954, cujo nome seria usado para qualificar a política de Krushev a partir de 1956. Mas na virada dos anos 1940 para os 1950 ele se mantinha um stalinista fiel, aliado do outro amigo e protetor soviético de Jorge Amado, Fadeiev, que se mataria em 1956 após as denúncias dos crimes de Stálin.

As memórias de Zélia Gattai e Jorge Amado fizeram inúmeras referências ao amigo Ilya, com quem estiveram muitas vezes em Paris, nos Congressos da Paz, no castelo de Dobris, em eventos oficiais ou particulares, por exemplo, em jantares no apartamento de Ehrenburg na rua Gorki, em Moscou, pequeno e repleto de livros, segundo Zélia Gattai (2009a: 207), em sua datcha [casa de campo], a cem quilômetros de Moscou (Gattai, 2010: 156), ou no modesto apartamento do casal brasileiro no Hôtel Saint-Michel, em Paris. Nesses eventos por vezes compareciam figurões do establishment cultural soviético, como Fadeiev e Korneichuk - escritor, vice-presidente do soviete supremo da Ucrânia em Kiev, membro do Comitê Central do PC soviético - além de outros camaradas, caso de Neruda e Guillén (Amado, 1994: 27-29).

Por sua vez, Ilya lembrou-se de Jorge e Zélia no sexto e último volume de suas memórias. Qualificou o baiano como "amigo chegado", para em seguida falar de Guillén, seus versos musicais e sua personalidade "um pouco infantil" (Ehrenburg, 1970: 235-237). Já o poeta cubano definiu o amigo soviético como um apaixonado pelo mundo literário da América Latina, de cuja "mais próxima amizade gozavam Jorge Amado, Neruda, Varela, Marinello...” (Guillén, 1985: 162). 
O latino-americano mais chegado ao escritor soviético parece ter sido Pablo Neruda, que o conheceu em 1936, na cidade de Madri, onde ocupava o posto de cônsul chileno e recebia amigos como Garcia Lorca, Alberti e Hernandez (Ehrenburg, 1970: 164). A presença de Ehrenburg foi expressiva ao longo das memórias de Neruda, como no episódio da venda do carregamento de vinhos de primeira linha que tinham sido confiscados pelos soviéticos da adega que Goebbels havia pilhado na França. Eles entraram no mercado moscovita misturados aos vinhos locais e pelo mesmo preço baixo. Detentor da informação privilegiada, o "irredutível inimigo do nazismo" comprou enorme estoque e servia o néctar aos amigos que o visitavam em Moscou (Neruda, 1974: 247). ${ }^{12}$

\section{INFERNO E CÉU}

Jorge Amado escreveu que teve sua primeira dúvida em relação ao comunismo quando soube - em conversa de bar com amigos de Budapeste, em 1951 - que camaradas foram torturados pela polícia política do governo da Hungria durante o processo Rajk, num acerto de contas da cúpula dirigente (Amado, 1994: 29-30). Naquele mesmo ano, o romancista recebeu o prêmio Stálin e saiu no Brasil o livro O mundo da paz, publicado pelo Editorial Vitória, ligado ao PCB, no qual omitiu suas dúvidas: "stalinista incondicional, silenciei o negativo como convinha" (1994: 233). O livro teria várias edições, assim como O cavaleiro da esperança, sobre Luiz Carlos Prestes, pelos quais Amado nunca teria recebido direitos autorais (1994: 322). O escritor também teria dado 90\% de seu salário ao Partido quando exerceu mandato de deputado federal constituinte (Amado, 1994: 216).

Por sua vez, Zélia recordou que as dúvidas sobre o comunismo teriam surgido quando souberam, em Moscou, que seu amigo e dirigente comunista tchecoslovaco, Artur London, foi preso em 1951, por ocasião do processo Slansky, em que foi acusado de conspiração trotskista-titoísta-sionista junto com outros 14 dirigentes, onze dos quais seriam executados. Eram, em sua maioria, judeus como London, que pegou prisão perpétua, mas seria perdoado e solto em 1955 (Gattai, 2009b: 133). Jorge suporia, na época, que os renegados enganaram London, pois "seria impossível a Zélia e a mim acreditar que Gerard [nome de guerra de London], herói da Espanha e da Resistência, o mais leal dos comunistas, seja um traidor" (Amado, 1994: 241).

Em vários momentos de Jardim de inverno, Zélia Gattai narrou o mal-estar no castelo dos escritores com a atmosfera persecutória. Era o "tempo do medo e da solidão", que, entretanto, não abalava a fé em Stálin, nem impedia que seguissem normalmente as reuniões do Conselho da Paz, as viagens frequentes dos artistas e intelectuais envolvidos com ele, bem como a vida cotidiana no castelo de Dobris, onde, certo dia, Zélia e Jorge abriram as portas para receber a 
amiga Lise, mulher do perseguido London, e seus filhos, sob o olhar reprovador de outros moradores. Durante estada em Budapeste, ainda quando morava em Paris, Amado teve atendido um pedido para visitar o filósofo Lukács, então caído em desgraça, e com quem travara contato no Congresso de Wroclaw. Mais tarde, em Bucareste, pôde visitar o romancista Zaharia Stancu, que fora destituído da secretaria geral dos escritores romenos. Naquelas "semanas e meses infelizes" no castelo de Dobris, segundo Amado, cresciam as dúvidas e as noites insones em que ele e Zélia se contemplavam com "um nó na garganta, vontade de chorar" (Amado, 1994: 241-244; Gattai, 2009a: 361; 2009b: 86).

O castelo de Dobris continuava aberto para visitas menos polêmicas de artistas comunistas, como Anna Seghers, animando o cotidiano de Zélia e Jorge. Lá se promoviam comemorações, entre as quais o batizado laico de Paloma Gattai Amado, nascida em Praga. Foi uma "festa de arromba", com caviar e vodca trazidos de Moscou por Ehrenburg, padrinho da garota ao lado de Neruda e Guillén. O champanha ficou por conta do casal Lafitte (aquele que aconselhara Zélia a não se envolver nos assuntos internos do partido tchecoslovaco), além de sanduíches e bolos. Na mesma ocasião foi batizada a filha do pintor chileno José Venturelli, que recebeu o nome de Paz e teve vários padrinhos, entre os quais os poderosos soviéticos Fadeiev e Korneichuk, o presidente da União dos Escritores tchecos Jan Drda, e o poeta turco Nazim Hikmet, todos amigos de Amado (Gattai, 2009b: 169). Neruda e Guillén já haviam estado presentes como padrinhos na celebração mais modesta do "batizado" de João Jorge, realizada no hotel em que os Amado viveram em Paris, tendo como "padre" o escritor Alfredo Varela (Gattai, 2009a: 137-139; Guillén, 1985: 121-122).

Naquele "tempo do medo e da solidão", no final de 1951, Jorge Amado ganhou o cobiçado prêmio Stálin, como se viu. Foi também, então, que ele e mulher receberam da União dos Escritores Chineses o "convite dos sonhos" de Zélia para conhecer a China (2009b: 173). Viviam no paraíso, mas divisavam o inferno a poucos passos, reservado aos dissidentes. Naquele momento, Amado escrevia Os subterrâneos da liberdade, tido como ponto máximo do realismo socialista no Brasil (Gattai, 2009b: 13, 121; 2011: 42-43, 104).

$\mathrm{Na}$ época, Diógenes Arruda Câmara era, na prática, o principal dirigente do PCB, devido ao rígido isolamento na clandestinidade a que estava submetido o secretário geral, Luiz Carlos Prestes. Quando visitou Amado no castelo de Dobris, Arruda teria pedido uma cópia da obra, ainda inconclusa. Devolveria o texto dois anos depois, já no Brasil, com anotações à margem. O autor ignoraria as intervenções de Arruda e publicaria o livro intacto com o aval de dois leitores poderosos, Prestes e Giocondo Dias, segundo Zélia Gattai (2009: 121-123). Ao que tudo indica, tratava-se de afirmação interna de poder de Arruda, pois o livro era no essencial afinado com a visão dos principais dirigentes partidários sobre a luta de resistência ao Estado Novo no Brasil. Os líderes comunistas apareciam como heróis e os dissidentes amargavam a condição de vilões. Era o caso do 
personagem Saquila, inspirado em Hermínio Sacchetta, sem que jamais Amado tenha se desculpado pela caricatura, como apontou o ex-dirigente comunista Jacob Gorender (1998: 179).

A ficção de Amado de 1942 a 1954 não teria sido menos cruel com seus adversários do que os stalinistas de carne e osso, como interpretou Alfredo Wagner de Almeida, para quem todos os dissidentes tendiam a ser vistos como trotskistas, "apresentados como traidores, dados a aleivosias, cultivadores de um intelectualismo estéril e de teorizações supérfluas"; o dissidente era qualificado nessas obras com adjetivos como canalha, infame, mesquinho e traidor (Almeida, 1979: 200-201).

As atividades militantes de Jorge Amado ocupavam demais o tempo, levando sua produção literária a um compasso lento, sua carreira de escritor estaria sendo sacrificada "para cumprir tarefas políticas", como constatou Zélia Gattai, com uma ponta de indignação (2009b: 179). "Para um escritor que vive do trabalho literário, ficar oito anos sem livro novo nas livrarias é um desastre" (Gattai, 2011: 42).

De fato, a produção da Amado - que fora de um romance novo a cada um ou dois anos, de 1933 a 1946 - caiu sobremaneira no seu período de militância comunista mais ativa, de 1945 a 1956. Foram oito anos entre a publicação de Seara vermelha, em 1946, e Os subterrâneos da liberdade, em 1954. No intervalo entre eles saiu O mundo da paz, de 1951, contanto as viagens de Amado pelo bloco comunista, em relato tão alinhado com o stalinismo que o autor posteriormente vetou a reedição do livro. Ademais, a maior parte do que escreveu tinha ligação direta com sua atividade política, também em Os subterrâneos da liberdade.

Se a produção literária de Jorge Amado entrara em ritmo lento, havia a compensação da visibilidade que sua obra ganhou com os contatos políticos e culturais realizados, sobretudo, no exterior, que ampliaram enormemente sua fama e a difusão de seus livros, traduzidos cada vez em maior número para diversas línguas. A inserção na rede comunista e a atuação no movimento internacional da paz, potencializados a partir da estada em Paris, em parte envolviam certa perda de autonomia como escritor, mas, paradoxalmente, estabeleciam ou aprofundavam os contatos internacionais que permitiriam a Jorge Amado ser o autor brasileiro mais conhecido e publicado em todo o mundo. Formava-se seu público e garantia-se um reconhecimento entre os pares que perdurariam depois que deixou o PCB, sem alarde, para não hostilizar antigos companheiros no Brasil e no exterior, nem seu público de esquerda, e muito menos a União Soviética. Ele continuaria ligado ao movimento pela paz e sendo editado com sucesso nos países comunistas, enquanto ganhava autonomia e consagração como escritor. 


\section{CONCLUSÃo}

Havia nas matérias da imprensa cultural comunista francesa sobre a América Latina, no começo da Guerra Fria, uma celebração de aspectos da cultura popular e do realismo, bem como certo encanto com as tradições pré-colombianas, além da mística em torno de povos de um continente distante. Dava-se algum espaço a artistas social e politicamente engajados, afinados com a linha programática realista do PCF, a valorizar supostas fontes populares nacionais, em contraste com o formalismo cosmopolita, supostamente aliado do imperialismo. Artistas que viveram em Paris e se integraram ao círculo de Aragon e do movimento internacional pela paz foram os mais destacados, casos de Neruda, Amado, Guillén e Asturias.

A publicação de escritores latino-americanos e de matérias sobre a cultura da região na imprensa comunista reiterava o internacionalismo e a solidariedade entre os comunistas. Ademais, demonstrava aos leitores franceses que artistas e intelectuais da América Latina estavam afinados com as posições do PCF e da União Soviética no contexto internacional da Guerra Fria. Seu apoio comprovaria a justeza das posições do lado socialista, capaz de atrair os melhores corações e mentes.

Por sua vez, a difusão de obras de artistas latino-americanos na imprensa comunista francesa contribuiria para seu sucesso internacional. A experiência do exílio e da integração à rede cultural comunista, a partir de Paris, também traria ganhos para sua formação e carreira profissional, como se viu no caso exemplar de Jorge Amado, divulgador e expoente, no Brasil, do realismo socialista internacional. As recompensas, entretanto, colocavam dilemas para os artistas que testemunhavam as perseguições a militantes dissidentes em escala internacional. Ademais, eles se inseriam nas redes comunistas como reprodutores do pensamento e da política produzida no centro, não como formuladores originais. Reiterava-se a relação centro-periferia tão comum na relação de artistas e intelectuais latino-americanos com as metrópoles europeias.

Conforme já se explicitou em texto anterior, ${ }^{13}$ o vínculo de artistas e intelectuais com o movimento comunista não poderia ser resumido em equações simples, como supor que se tratava de mero desejo de transformar seu saber em poder, nem que artistas e intelectuais eram idealistas manipulados e vigiados pelos dirigentes comunistas, com o uso indevido e despótico da arte para fins que lhes seriam alheios. Havia uma relação intrincada - material e simbólica, objetiva e subjetiva - entre todos os sujeitos envolvidos. 
ARTIGO | MARCELO RIDENTI

Marcelo Ridenti é professor titular de Sociologia na Universidade Estadual de Campinas (Unicamp) e pesquisador do Conselho Nacional de Desenvolvimento Científico e Tecnológico (CNPq). É autor de diversos livros, sendo o mais recente Brasilidade revolucionária: um século de cultura e política (2010). 


\section{NOTAS}

1 Esse artigo resulta estágio de pós-doutoramento na École de Hautes Études em Sciences Sociales (EHESS), em Paris, de novembro de 2009 a fevereiro de 2010. Acordo Capes-Cofecub n527/2006, coordenado por Denis Rolland e Daniel Aarão Reis. Agradeço, também, a Afrânio Garcia e Michael Löwy, interlocutores na França. O texto tem caráter, sobretudo, narrativo, de reconstituição de uma história ainda pouco conhecida e estudada. As várias notas de rodapé remetem às fontes, mas foram elaboradas de tal forma que podem ser dispensáveis para uma leitura mais fluente.

2 Sobre artistas e intelectuais do PCF, ver, por exemplo, as obras de Caute (1967), Khilnani (1993), Matonti (2005), e Verdès-Leroux $(1983 ; 1987)$.

3 “O fato é que desde então (1949-1950), as tarefas principais dos comunistas brasileiros passaram a ser reflexo e parte das tarefas internacionais: campanhas de assinaturas contra a bomba atômica, em favor do apelo de Estocolmo, reuniões nacionais preparatórias de congressos internacionais - de jovens, escritores, mulheres, operários, camponeses - pela paz mundial", nos termos do jornalista e ex-dirigente do $\mathrm{PCB}$ Osvaldo Peralva em O retrato (1960: 46-47). O livro de (auto) crítica foi publicado na esteira das denúncias dos crimes de Stálin. Jorge Amado afirmaria que tudo que foi contado nessa obra "é a expressão da verdade" (Amado, 1994: 321). Ver, ainda, Dênis de Moraes (1994).

4 Ainda em referência à Cuba pré-castrista, foi celebrado o centenário de "José Marti, escritor e combatente", em artigo do escritor cubano Juan Marinello. Após a revolução, Marinello seria nomeado reitor da Universidade de Havana em 1962; faria parte do Comitê Central do PC cubano de 1965 até a morte, em 1977.

5 Sobre o caso da capa polêmica, ver, por exemplo, Gertje Utley (2000: 181-190). Picasso filiara-se ao PCF em 4 de outubro de 1944. O evento foi destacado no dia seguinte na capa de L'Humanité, que celebrou a entrada do "maior pintor vivo" na "família comunista" (L’Humanité, 5 de outubro de 1944, p. 1). Picasso nunca abandonaria a afiliação comunista.

6 Brecht, o célebre teatrólogo comunista que morava em Berlim Oriental, era tema recorrente no periódico, que o tratava com reverência e elogio. 
7 Getúlio Vargas - então presidente eleito do Brasil - foi mencionado na matéria como ditador.

8 O realismo socialista puro e duro seria trazido na bagagem de Amado e difundido na coleção Romances do povo, dedicada, sobretudo, a estrangeiros, em particular os soviéticos. Três obras de autores brasileiros, duas delas publicadas na coleção, costumam ser classificadas como exemplos acabados do realismo socialista no Brasil. Não por acaso, foram editadas também na União Soviética. Trata-se de A hora próxima, de Alina Paim, sobre a greve de ferroviários com realce ao papel das mulheres; Os posseiros, de Maria Alice Barroso, acerca de lutas camponesas em Minas Gerais; e Linha do parque, obra do paraense Dalcídio Jurandir, enviado a Porto Alegre para escrever sobre o movimento operário gaúcho. Esses livros destacariam o papel heroico e de vanguarda do militante comunista; seus autores eram muito ligados a Jorge Amado na época, segundo Alfredo Wagner Almeida, que analisou a "literarura de partido" do baiano. Os subterrâneos da liberdade seriam a única obra brasileira de peso ligada à corrente do realismo socialista, com sucesso de público e reedições ao longo do tempo (Almeida, 1979: 217).

9 Amado ajudou, por exemplo, na premiação a Nelson Pereira dos Santos como Jovem Realizador de Rio, 40 graus num festival na Tchecoslováquia, em julho de 1956. "Jorge Amado, amigo de Joris Ivens e Pudovkin, mais uma vez contribuíra a favor do filme: 'Estive lá um pouco antes, preparei o terreno para o Nelson. Eu me dava bem com aquela gente, a começar pelos soviéticos'” (Salem, 1987: 122).

10 O contato fora realizado na França no fim da década de 1940, mas a amizade estabeleceu-se, de fato, no Brasil, como atestam não só as memórias de Jorge Amado (1994: 208-209), e de Zélia Gattai (2009a: 314; e 2011: 89), mas também as de Simone de Beauvoir. A escritora francesa dedicou cerca de 50 páginas para comentar as aventuras dela e de Sartre no Brasil, acompanhados quase todo o tempo pelo casal brasileiro, em 1960: "Sentíramos uma simpatia imediata por Jorge e Zélia; no Rio, tornamo-nos íntimos: não pensávamos, na nossa idade, [...] conhecer ainda a alegria de uma amizade nova" (Beauvoir, 1995: 464). De retorno a Paris, logo os franceses publicaram com destaque, na 
abertura do $\mathrm{n}^{\circ} 178$ de sua célebre revista, o texto recente de Amado Les trois morts de Quinquin-la-flotte (Les Temps Modernes, 1961: 868-915).

11 O periódico dava espaço a pintores comunistas que eram do círculo de Aragon, embora distantes do realismo socialista, como Picasso e Leger, enquanto Fougeron era o pintor alinhado por excelência com a posição do PCF nas artes. A consagração de Picasso e de Leger antes de entrar no PCF, mais sua dedicação à causa da paz, davamlhes possibilidade de continuar no partido e desenvolver suas obras autonomamente, apesar das críticas de alguns dirigentes. Ver a respeito, por exemplo, as obras de Berthet (1990), e de Utley (2000). No Brasil, Portinari pôde conservar distância do realismo socialista de Zdanov, afinal já era um artista consagrado quando aderiu ao PCB na conjuntura da redemocratização pós-1945.

12 O episódio também foi relatado por Jorge Amado (1994: 128-129), e por Zélia Gattai (2009a: 214-216). Era um prazer para os artistas comunistas brindar com o espólio da adega nazista.

13 Para uma exposição mais detalhada da importância das redes comunistas na cultura brasileira dos anos 1950, ver meu artigo "Brasilidade vermelha" (Ridenti, 2008), depois publicado como capítulo do livro Brasilidade revolucionária (Ridenti, 2010: 57-83).

\section{REFERÊNCIAS BIBLIOGRÁFICAS}

Almeida, Alfredo Wagner Berno de. Jorge Amado: política e literatura. Rio de Janeiro: Campus, 1979.

Amado, Jorge. Navegação de Cabotagem: apontamentos para um liuro de memórias que jamais escreverei. 3.ed. Rio de Janeiro: Record, [1992] 1994. ; Pomar, Pedro \& Neruda, Pablo. O Partido Comunista e a liberdade de criação. Rio de Janeiro: Horizonte, 1946.

Aragon, Louis. Les communistes. Paris: Bibliothéque Française, 1949-1951 (6 vol.).

Arts de France, 1946, 9.

Beauvoir, Simone. A força das coisas. Rio de Janeiro: Nova Fronteira, [1963] 1995. 
Berthet, Dominique. Le P.C.F., la culture et l'art (1947-1954). Paris: La Table Ronde, 1990.

Caute, David. Le communisme et les intellectuels français, 19141966. Paris: Gallimard, 1967.

Daix, Pierre. Aragon: une vie à changer. Paris: Flammarion, 1994.

Ehrenburg, Ilya. No entardecer da vida: memórias (1945-1953). Rio de Janeiro: Civilização Brasileira, 1970.

Europe, 1948a, 25. , 1948b, 29. , 1949a, 45. ,1949b, 47-48. , 1950, 49 . , 1951a, 66. , 1951b, 67-68.

Gattai, Zélia. Senhora dona do baile: memórias. São Paulo: Companhia das Letras, [1984] 2009a.

. Jardim de inverno: memórias. São Paulo: Companhia das Letras, [1988] 2009b.

. Um chapéu para viagem: memórias. São Paulo: Companhia das Letras, [1982] 2010.

Chão de meninos: memórias. São Paulo: Companhia das Letras, 2011 [1992].

Gorender, Jacob. Combate nas trevas. 5.ed. São Paulo: Ática, [1987] 1998.

Guillén, Nicolás. Páginas cubanas: autobiografia de um poeta na revolução. São Paulo: Brasiliense, [1982] 1985.

Khilnani, Sunil. Arguing revolution: intelectual left in postwar France. New Haven/Londres: Yale University Press, 1993.

Kriegel, Annie. Ce que j'ai cru comprendre (mémoires). Paris: Robert Laffont, 1991.

La Nouvelle Critique, 1954, 60.

Les Lettres Françaises, 1948a, 197. 1948b, 199. 1948c, 202. ,1948d, 209. 1948e, 234. 
, 1950a, 295.

, 1950b, 332.

, 1951a, 351.

, 1951b, 353.

, 1952, [número desconhecido] 2 de maio.

,1953a, 456.

, 1953b, 483.

, 1954a, 498.

, 1954b, 505.

, 1954c, 508.

, 1954d, 510.

, 1954e, 522.

, 1955, [número desconhecido] 20 de janeiro.

, 1956a, 607.

, 1956b, 614

, 1957a, 664 .

, 1957b, 678.

, 1957c, 690 .

, 1958, 718.

, 1959a, 756.

, 1959b, 774.

, 1959c, 778.

Les Temps Modernes, 1961, 178.

Matonti, Frédérique. Intelectuels communistes: essai sur مै l'obéiance politique. Paris: Découverte, 2005.

今े Moraes, Dênis de. O imaginário vigiado: a imprensa comunista ڤ̂n $\quad$ o realismo socialista no Brasil (1947-53). Rio de Janeiro: José iे Olympio, 1994.

Neruda, Pablo. Confesso que vivi: memórias. 5.ed. Rio de Janeiro: Difel, 1974.

Peralva, Osvaldo. O retrato. Belo Horizonte: Itatiaia, 1960.

Ridenti, Marcelo. Brasilidade vermelha. In: Botelho, André; Bastos, Elide Rugai \& Villas Bôas, Glaucia (orgs.). O moderno em questão: a década de 1950 no Brasil. Rio de Janeiro: Topbooks, 2008, p. 169-209 
Brasilidade revolucionária: um século de cultura e política. São Paulo: Ed. Unesp, 2010.

Salem, Helena. Nelson Pereira dos Santos: o sonho possível do cinema brasileiro. Rio de Janeiro: Nova Fronteira, 1987.

Souza, José Inácio Melo. Paulo Emílio no paraíso. Rio de Janeiro: Record, 2002.

Strada, Vittorio. Do realismo socialista ao zdhanovismo. In: Hobsbawn, Eric (org.). História do marxismo. 2.ed. Rio de Janeiro: Paz e Terra, 1987 (Vol. 9).

Utley, Gertje. Picasso: the communist years. New Haven/ Londres: Yale University Press, 2000.

Verdès-Leroux, Jeannine. Au service du Parti: Le Parti Communiste, les intellectuels et la culture (1944-1956). Paris: Fayard-Minuit, 1983.

Le réveil des somnambules: Le Parti Communiste, les intellectuels et la culture (1956-1985). Paris: Fayard-Minuit, 1987. 
Resumo:

O artigo busca elucidar aspectos da relação de artistas brasileiros e latino-americanos com a imprensa cultural comunista francesa e com o movimento comunista internacional do fim dos anos 1940 a meados dos 1950, no contexto da Guerra Fria. Os contatos no exterior foram fundamentais para a inserção internacional de latinoamericanos, bem como para sua formação intelectual e política. A imprensa comunista francesa desempenhou papel importante para divulgar a obra de artistas latinoamericanos, notadamente os que moraram em Paris. Alguns deles conseguiram lugar de destaque na rede comunista, especialmente por sua atuação no movimento pela paz mundial, como o poeta chileno Pablo Neruda e o romancista brasileiro Jorge Amado. Ele foi o principal artista brasileiro a beneficiar-se da internacionalização a partir do exílio em Paris, abrindo caminho também para a difusão de obras de amigos estrangeiros no Brasil e de brasileiros no exterior. São abordados ainda os dilemas dos artistas comunistas diante das perseguições e recompensas no auge do stalinismo.
Palavras-chave:

Artistas comunistas;

Realismo socialista; Jorge Amado; Imprensa comunista francesa; Conselho Mundial da Paz.
Keywords:
Artists communists;
Socialist realism;
Jorge Amado; French
Communist press;
World Peace Council.

The article seeks to elucidate aspects of the relationship of Latin American artists with the French Communist press and the international communist movement in the context of the Cold War. The overseas contacts were crucial for the international insertion of Latin Americans, as well as for their intellectual and political education. The French Communist press has been important to promote the work of Latin American artists, especially those who lived in Paris. Some of them managed to get a place in the communist network. The Chilean poet Pablo Neruda and the Brazilian novelist Jorge Amado have played a relevant role in the movement for world peace in the late 1940s and the 1950s. Amado has been the main Brazilian artist to benefit from the internationalization, also paving the way for the dissemination of works of his foreign friends in Brazil and Brazilians abroad. The article analyses also the dilemmas faced by communist artists: persecution and rewards in the heyday of Stalinism. 